\title{
QUALITY OF LIFE AND WELL-BEING OF POPULATION AT THE END OF THIRD PHASE OF LOCKDOWN IN INDIA AGAINST THE COVID-19 PANDEMIC
}

\author{
H. Rathi' ${ }^{1}$, M. Biyani' ${ }^{2}$ M. Malik ${ }^{3},{ }^{*}$ P. Rathi ${ }^{4}$ \\ 1 - RUHS COLLEGE OF MEDICAL SCIENCES, JAIPUR, INDIA \\ 2 - SWAI MAN SINGH MEDICAL COLLEGE, JAIPUR, INDIA \\ 3 - PANDIT DEENDAYAL UPADHYAYA MEDICAL COLLEGE, CHURU, INDIA \\ 4 - MAHATMA GANDHI MEDICAL COLLEGE AND HOSPITAL, JAIPUR, INDIA
}

Background. On March 24, 2020, a nationwide Lockdown for 21 days was ordered by the Government of India which was then extended till May 31, 2020. Researchers have predicted lockdown is a necessary step to prevent COVID-19 spread. However, others have also stated that it could cause serious damage to the economic, mental, social, and physical well-being of the people.

Objective. The aim of the study is to evaluate the impact of lockdown on the quality of life and well-being of the Indians.

Methods. It is a cross sectional prospective web-based questionnaire study. A link (https://forms.gle/ pX25VuahP5NxT88QA) was created. Total 426 responses were received via that link and the data was included in the statistical analysis.

Results. Our study revealed that during the lockdown $61.5 \%$ of the respondents were performing physical activities lesser than before. More than half responded they had a reduced financial satisfaction. Most answers on emotional well-being and social-family wellbeing were also positive, but some responses showed disturbing too, like 22\% felt anxious and nervous over half of the days. It was found in the study that physical, financial, emotional, mental, social and family wellbeing were disturbed during the lockdown and quality of life was also hampered.

Conclusion. Though, may be Nationwide Lockdown was the most required action at that point of time to prevent virus spread, but our study revealed that uncertainty regarding its cure and management guidelines like lockdown and social distancing has badly affected quality of life and wellbeing of the population.

KEYWORDS: pandemic; lockdown; COVID-19; anxiety; well-being.

\section{Introduction}

In December 2019, several cases of a disease having similar symptoms of pneumonia were reported in Wuhan city of China [1]. World Health Organisation (WHO) defined this disease as COVID-19. Genetically this virus is similar to severe acute respiratory syndrome corona virus (SARS-CoV). SARS CoV-2 strain is the causative agent for COVID-19. Patients of COVID-19 commonly present with symptoms of fatigue, cough, fever, myalgia, and diarrhoea. After China, this virus started spreading to the rest of the world. Its mode of transmission is inhalation of infectious aerosol. Reports revealed that COVID-19 transmission is possible through infected human contact. Due to interhuman transmission, soon it has become global health

\footnotetext{
*Corresponding author: Dr. Priyanka Rathi, Associate Professor, Mahatma Gandhi Medical College and Hospital, Jaipur, 302022, India. E-mail: drpriyankarathi@gmail.com
}

emergency worldwide. Because of its spread in 144 countries across five continents, the World Health Organisation declared COVID-19 as pandemic disease on March 12, 2020 [2].

By the end of November 2020 this pandemic has infected 70 million people worldwide and the number is increasing day by day. Like the rest of the world COVD-19 has been reported in India too. In India 9.3 million of population has been diagnosed with COVID-19 positive by November 2020. Meanwhile no drug therapy has been established for its prevention, control and cure till now. So, to deal with this Pandemic strict quarantine and lockdown are considered to be a highly effective and important preventive measure by almost the whole world. Following the footsteps, India also took the help of lockdown due to increasing number of cases of COVID-19. Nation underwent 4 phases of lockdown for nearly 70 days. 
The $1^{\text {st }}$ phase of lockdown started on March 24, 2020, for 21 days. Then, an increasing number of cases and severity of the disease forced Government to further extend it into phase 2 for 19 days, and phase 3 for 14 days. From May 18 phase 4 was announced which was planned to end on May 31, 2020. Strict guidelines were formulated to prevent its spread. Only essential services like medical and groceries services were allowed to keep open. Apart from the mentioned services everything else was closed. Based on the number of the cases in particular region, country was divided into 3 zones during the lockdown: green, orange, red.

Green zone covered the areas with zero confirmed cases till date or no confirmed cases in the past 21 days. Orange zone involved the areas, which reported a limited number of cases in the past and no surge of positive cases in recent times. Red zone is for the areas or hotspots classified as those with the highest caseload.

Although, the Lockdown was considered necessary to prevent COVID-19 spread. During the period of lockdown Indian residents are advised to stay at home. It hampered resident's life style very much. Some researchers stated this caused serious damage to emotional [3] economic, mental, psychological [4], social and physical well-being of the population. Due to a prolonged lockdown and business closure, people experienced negative emotions, stress, aggressiveness and anxiety symptoms. So, this study was aimed to evaluate the impact of lockdown on the quality of life and wellbeing of Indians.

\section{Methods}

A cross-sectional web-based online survey was conducted for a period of two weeks starting just after the completion of third phase of lockdown in India, from May 25 to June 1, 2020. A survey link (https://forms.gle/ pX25VuahP5NxT88QA) was created through a web-based Google application of 'Google Form'. All Indian citizens above the age of 18 years old, who gave an informed consent for participation in the study, were included while NRI and foreign citizens were excluded. Participants were recruited by sending the survey link through various social network channels such as WhatsApp, LinkedIn, Instagram, and Facebook. The final sample was obtained using the snowball technique wherein each participant was requested to further circulate the survey link among their respective family members, friends, and colleagues. The obtained data were analysed.

Study tools counted in a pre-validated 47item online questionnaire, which was validated for relevance, clarity, simplicity, and ambiguity by using 4- and 5-point content validity index. An informed consent document comprising the participant information sheet and informed consent form in Hindi and English was suggested in the beginning of the questionnaire and only those participants, who gave their consents, were allowed further access to the questionnaire. The questions were in both languages in the questionnaire. The variables and instruments included in the questionnaire comprise the following:

1. Section 1 with 13 questions on demographics of the participants including age, gender, marital status, educational and professional details, area of residence and its COVID zone, and present state of health.

2. Section 2 with 34 questions for the assessment of physical (02 questions), psychological (09 questions), financial (07 questions), emotional (06 questions), and social and family well-being (05 questions) of the participants and their quality of life (05 questions).

Questions related to physical wellness were generated ad hoc. For psychological well-being among the participants two tools were used, i.e. the Patient Health Questionnaire-2 (PHQ-2) [5] to screen for depression, and the Generalized Anxiety Disorder Scale (GAD-7) [6] to screen for anxiety. Both the tools consisted of 2 Likert type questions, each with 4 response options ranging from $0-3$. The PHQ-2 score ranged from $0-6$ with 3 as the optimal cut point while the GAD-7 score ranged from 0-21 with a score of 10 or higher indicates significant anxiety.

Financial well-being was evaluated using a modified COST-FACIT (Version 2) consisting of 7 questions, 6 which were Likert type questions with 5 response alternatives ranging from 0-4. FACIT-Sp (Version 4) was used to assess the physical, social/family and emotional well-being of the participants. For emotional well-being 6 Likert type questions and for social and family well-being 5 Likert type questions were asked, each with 5 response options ranging from 0-4. The WHO (Five) Well-Being Index (1998 version) consisting of 5 Likert type questions having 6 possible options was used to evaluate the quality of life of the study participants during the lockdown. The raw score ranged from 0 to 25; 0 representing the worst possible and 25 representing the best possible quality of life. 


\section{Results}

A total of 426 responses were received via the study link (https://forms.gle/ pX25VuahP5NxT88QA) of 'Google Form'. 421 participants gave their consent for participation and were included in the survey. Their demographic details are depicted in Table 1.

$4.8 \%$ of the participants responded that they were suffering from chronic health problems, the details are depicted in Fig. 1.

Physical well-being: $23.5 \%$ participants responded that during the lockdown, they were able to perform their routine physical activities as they used to do before the starting of lockdown, while $15 \%$ responded that they were not able to do so at all, and $61.5 \%$ could perform their routine physical activities lesser than before. Health related problems due to changes in daily routine, like drowsiness, weight gain, etc. were experienced by $28.8 \%$ participants.

Financial wellbeing (COST FACIT(Version 2)): Regarding satisfaction with their current financial situation consequent to lockdown, majority of the participants (57\%) responded

Table 1. Demographic details of the study participants

\begin{tabular}{|c|c|c|}
\hline \multicolumn{2}{|c|}{ Variables } & \multirow{2}{*}{$\begin{array}{c}\begin{array}{c}\text { No. of responses } \\
\text { (percentage) }\end{array} \\
267(63 \%) \\
154(36.3 \%) \\
\end{array}$} \\
\hline Gender & \begin{tabular}{|l} 
Males \\
Females
\end{tabular} & \\
\hline Age & $\begin{array}{l}18-45 \text { years old } \\
45-60 \text { years old } \\
\text { Above } 60 \text { years old }\end{array}$ & $\begin{array}{l}328(97.32 \%) \\
8(2.3 \%) \\
1(0.38 \%)\end{array}$ \\
\hline Marital status & $\begin{array}{l}\text { Unmarried } \\
\text { Married } \\
\text { Divorced/widowed }\end{array}$ & $\begin{array}{c}261(61.5 \%) \\
158(37.4 \%) \\
04(1.1 \%)\end{array}$ \\
\hline Education & \begin{tabular}{|l|} 
Graduate \\
Post-graduate \\
High school \\
Intermediate \\
\end{tabular} & $\begin{array}{c}232(54.8 \%) \\
154(36.4 \%) \\
5.2 \%(22) \\
3.6 \%(15) \\
\end{array}$ \\
\hline Occupation & \begin{tabular}{|l} 
Student \\
Service \\
Business \\
Housewife \\
\end{tabular} & $\begin{array}{c}190(45.8 \%) \\
122(29.3 \%) \\
53(12.7 \%) \\
33(7.9 \%) \\
\end{array}$ \\
\hline Type of service & \begin{tabular}{|l|} 
Not applicable \\
Private \\
Government \\
\end{tabular} & $\begin{array}{l}188(46.2 \%) \\
126(31 \%) \\
93(22.9 \%) \\
\end{array}$ \\
\hline Residence & \begin{tabular}{|l|} 
Urban \\
Rural \\
\end{tabular} & $\begin{array}{l}295(70.1 \%) \\
126(29.9 \%)\end{array}$ \\
\hline COVID Zone of the area of residence & \begin{tabular}{|l} 
Red zone \\
Orange Zone \\
Green Zone \\
Don't know \\
\end{tabular} & $\begin{array}{l}186(44.1 \%) \\
132(31.1 \%) \\
97(23.1 \%) \\
08(1.7 \%) \\
\end{array}$ \\
\hline During lockdown, living with & $\begin{array}{l}\text { Family } \\
\text { Initially stuck away then able to live } \\
\text { with family } \\
\text { Away from family }\end{array}$ & $\begin{array}{l}296(69.7 \%) \\
68(15.8 \%) \\
59(14.4 \%) \\
\end{array}$ \\
\hline $\begin{array}{l}\text { Whether profession is related to COVID } \\
\text { frontline fighting }\end{array}$ & $\begin{array}{l}\text { Yes } \\
\text { No }\end{array}$ & $\begin{array}{c}79(19.2 \%) \\
343(80.8 \%)\end{array}$ \\
\hline $\begin{array}{l}\text { Whether suffering from any chronic health } \\
\text { problem }\end{array}$ & $\begin{array}{l}\text { Yes } \\
\text { No }\end{array}$ & $\begin{array}{c}19(4.8 \%) \\
402(95.2 \%)\end{array}$ \\
\hline $\begin{array}{l}\text { Preferred to stay home during lockdown } \\
\text { because of }\end{array}$ & $\begin{array}{l}\text { Fear of strict government action } \\
\text { Fear of getting infected } \\
\text { Pressure from family }\end{array}$ & $\begin{array}{l}30(7.3 \%) \\
342(83 \%) \\
40(9.7 \%)\end{array}$ \\
\hline State of health at present & \begin{tabular}{|l} 
Excellent \\
Very good \\
Good \\
Fair \\
Poor
\end{tabular} & $\begin{array}{c}76(18.4 \%) \\
145(34.2 \%) \\
140(33 \%) \\
51(11.8 \%) \\
12(2.3 \%)\end{array}$ \\
\hline
\end{tabular}




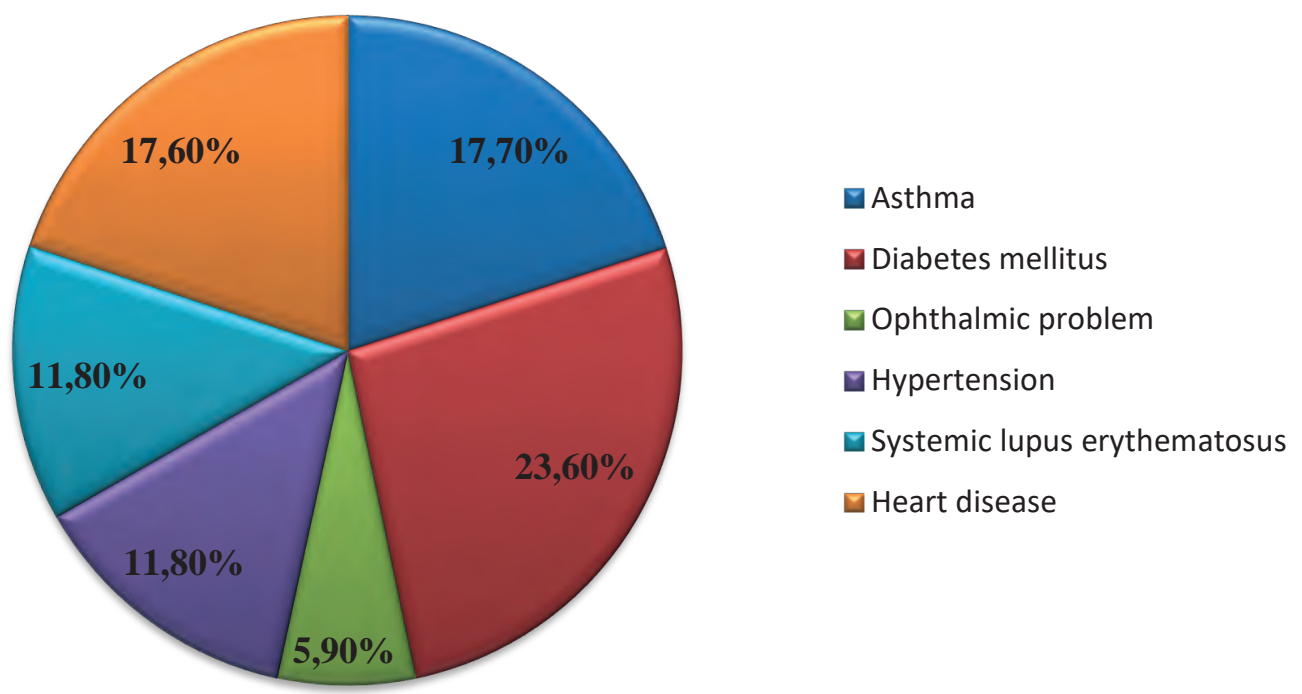

Fig. 1. Distribution of various chronic health problems among the study participants.

that they have a reduced satisfaction, $29.4 \%$ were satisfied, and $13.6 \%$ felt financially stressed.

Fig. 2 illustrates the responses of the participants to the COST FACIT Likert questions on financial well-being.

Fig. 3 illustrates the responses of the participants to the FACIT-Sp (version 4) Likert questions on emotional Wellbeing.

Fig. 4 illustrates the responses of the participants to the FACIT-Sp (version 4) Likert Social and family well-being.
Psychological well-being: Responses regarding mental well-being are shown in Table 2.

Table 3 depicts the scores for PHQ-2, GAD-7, and WHO well-being index.

Fig. 5 illustrates the responses of the participants on the quality of life (WHO Well-Being Index (1998 version)).

\section{Discussion}

The study population consisted of 426 participants: 421 participants were fulfilling inclusion and exclusion criteria. The present

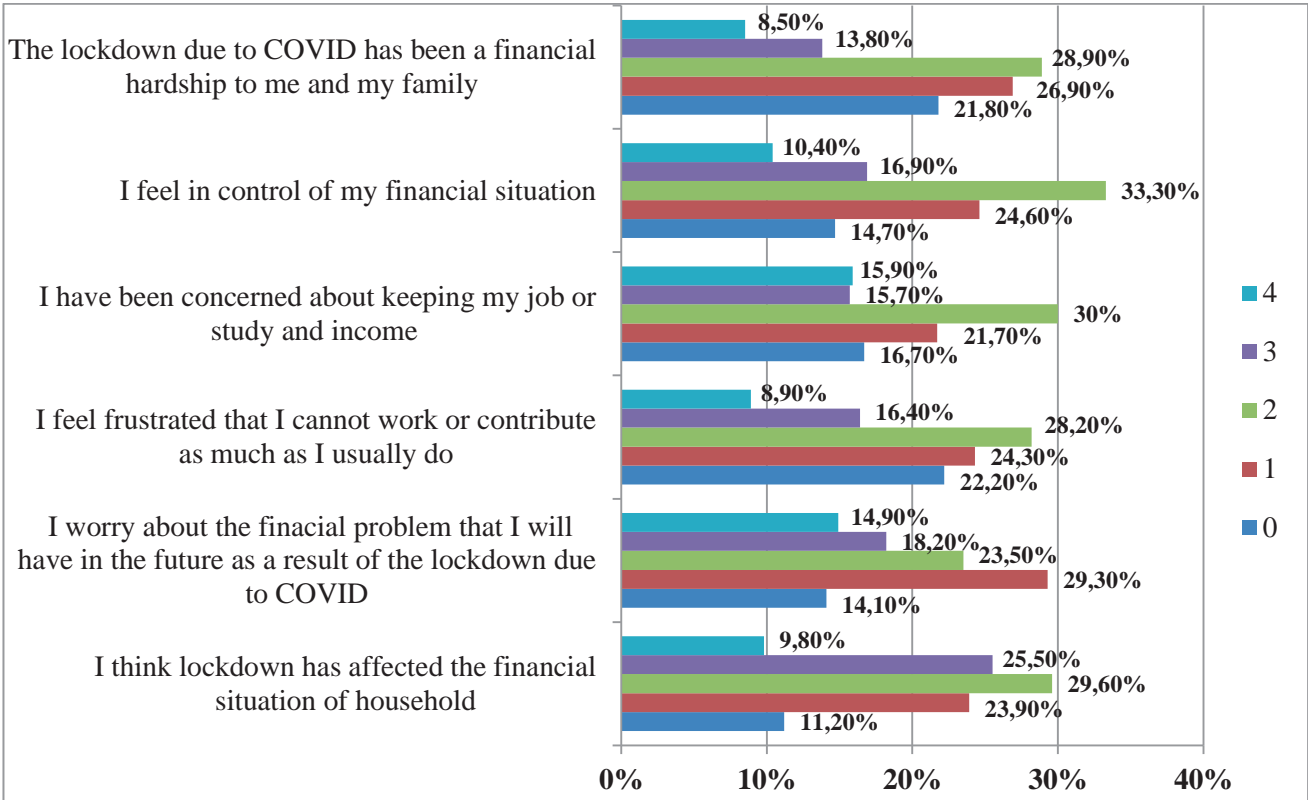

Fig. 2. Participants responses ( 0 - not at all, 1 - a little bit, 2 - somewhat, 3 - quite a bit, 4 - very much) to statements on financial well-being in COST FACIT (Version 2) 


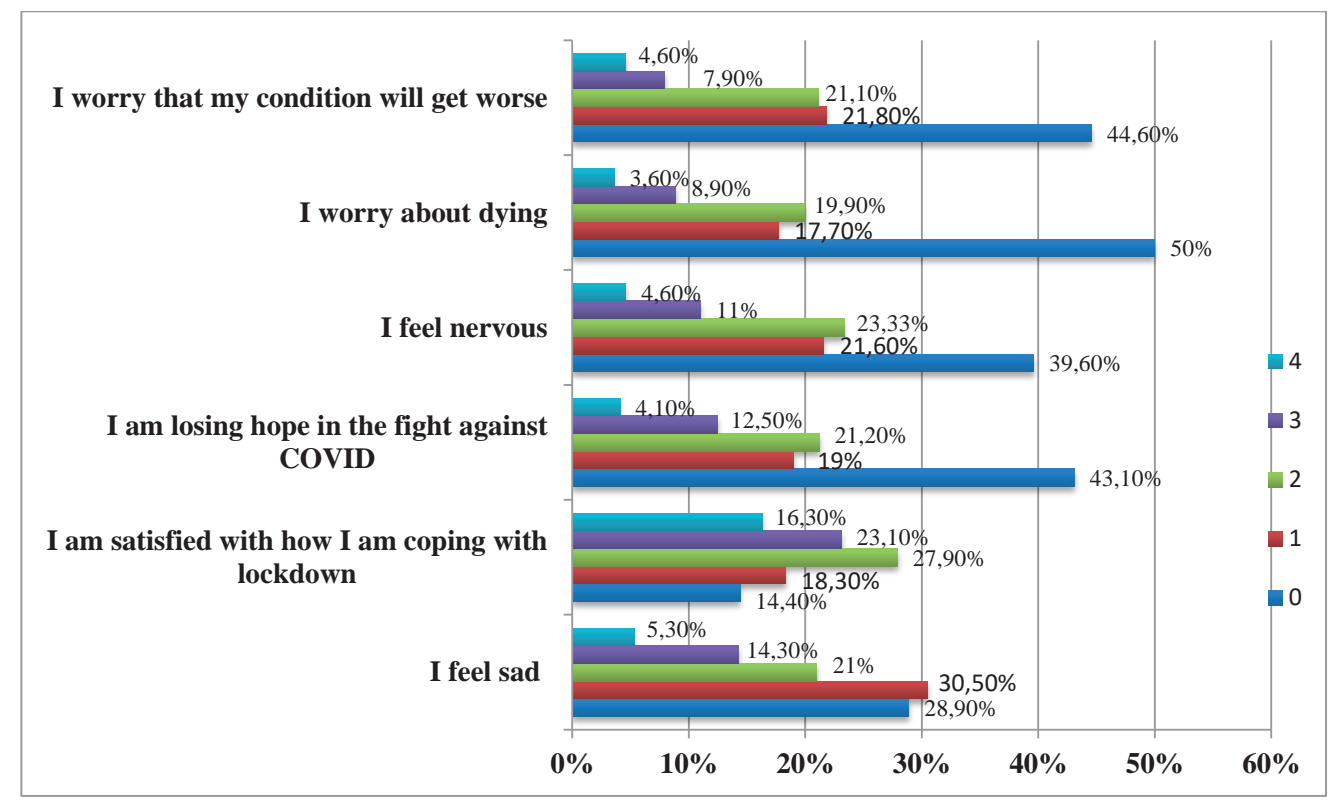

Fig. 3. Participants responses ( 0 - not at all, 1 - a little bit, 2 - somewhat, 3 - quite a bit, 4 - very much) to statements on emotional well-being in FACIT-Sp (Version 4).

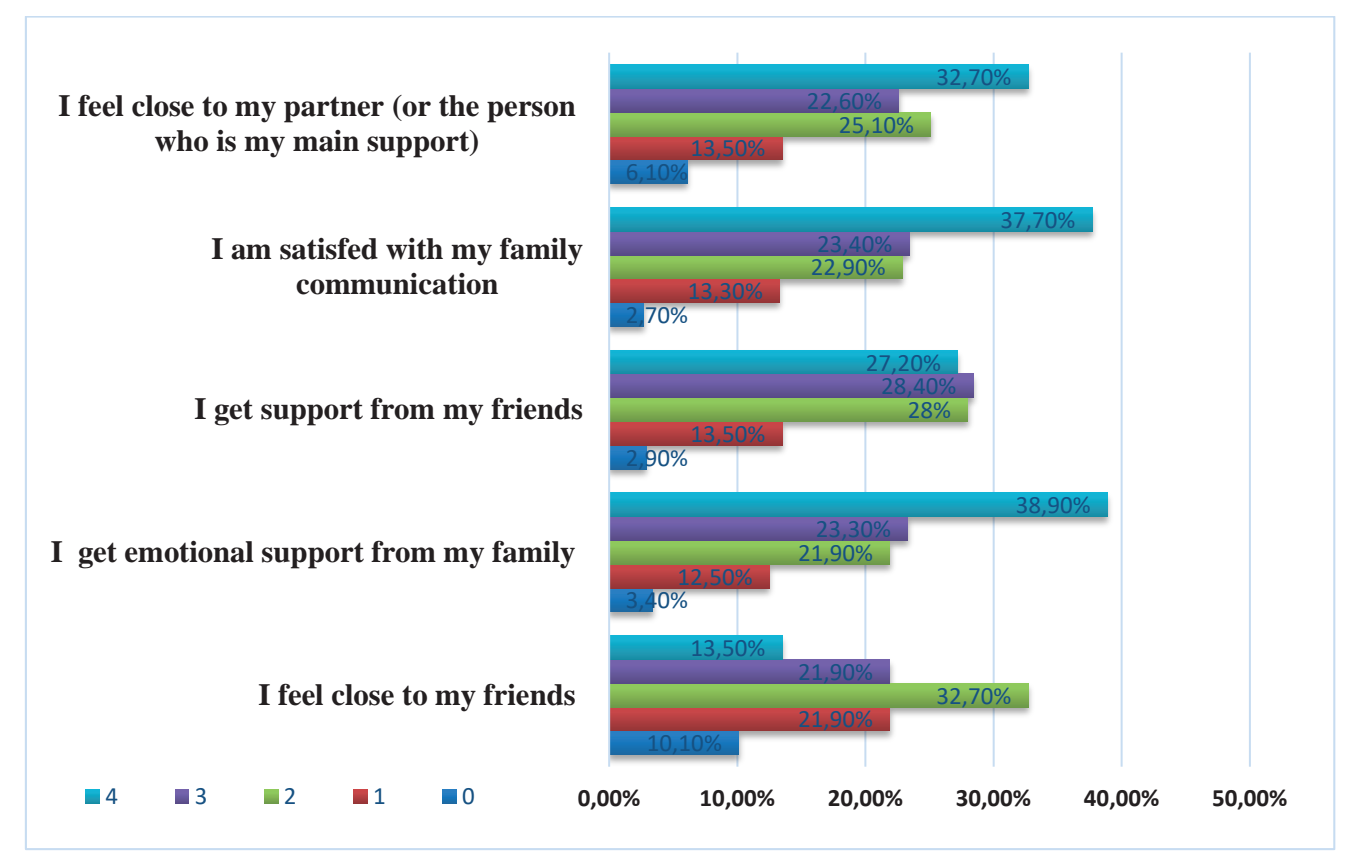

Fig. 4. Participants responses ( 0 - not at all, 1 - a little bit, 2 - somewhat, 3 - quite a bit, 4 - very much) to statements on social and family well-being in FACIT-Sp (Version 4).

study emphasizes to all types of well-being (physical, psychological, financial, emotional, social, family and quality of life) of Indian population during the lockdown due to spread of COVID-19. Although, the lockdown was thought to be the most effective way to prevent the spread of COVID-19, it has also negatively affected the quality of life and well-being of population.
People faced a lot of physical health related problems during this period. $61.5 \%$ study population responded that they were not able to perform their physical activities as before, $28.8 \%$ of the participants felt physical changes in their body. Majority of the participants (39.1\%) felt lesser interest in doing things for several days. Similarly, 33.7\% felt down depressed for hopeless for several days during 
Table 2. Generalized Anxiety Disorder Scale (GAD-7)

\begin{tabular}{|l|c|c|c|c|}
\hline & $\begin{array}{c}\text { Not at all } \\
(0)\end{array}$ & $\begin{array}{c}\text { Several } \\
\text { days (1) }\end{array}$ & $\begin{array}{c}\text { Over half } \\
\text { the days (2) }\end{array}$ & $\begin{array}{c}\text { Nearly every } \\
\text { day (3) }\end{array}$ \\
\hline Feeling nervous, anxious or on edge & $37.8 \%$ & $34 \%$ & $22 \%$ & $6.2 \%$ \\
\hline Not being able to stop or control worrying & $35.2 \%$ & $33.5 \%$ & $22 \%$ & $9.3 \%$ \\
\hline Worrying too much about different things & $35.2 \%$ & $32.3 \%$ & $23 \%$ & $9.6 \%$ \\
\hline Trouble relaxing & $39.1 \%$ & $31.2 \%$ & $22.8 \%$ & $7 \%$ \\
\hline Being so restless that it's hard to sit still & $46.4 \%$ & $26.8 \%$ & $21.5 \%$ & $5.3 \%$ \\
\hline Becoming easily annoyed or irritable & $37.2 \%$ & $30.9 \%$ & $23.7 \%$ & $8.2 \%$ \\
\hline Feeling afraid as if something awful might happen & $38.8 \%$ & $33.1 \%$ & $20.1 \%$ & $7.9 \%$ \\
\hline
\end{tabular}

Table 3. Population distribution of PHQ-2, GAD-7, and WHO well-being index score

\begin{tabular}{|l|c|c|}
\hline \multicolumn{1}{|c|}{ Name of Score } & Score Range & No. of responses (percentage) \\
\hline PHQ-2 & $3-6$ & $90(21.12 \%)$ \\
& $0-2$ & $336(78.88 \%)$ \\
\hline GAD-7 & 10 or higher & $135(31.66 \%)$ \\
& Below 10 & $291(68.34 \%)$ \\
\hline WHO Well-Being Index & 13 or higher & $275(64.56 \%)$ \\
& Below 13 & $151(35.44 \%)$ \\
\hline
\end{tabular}

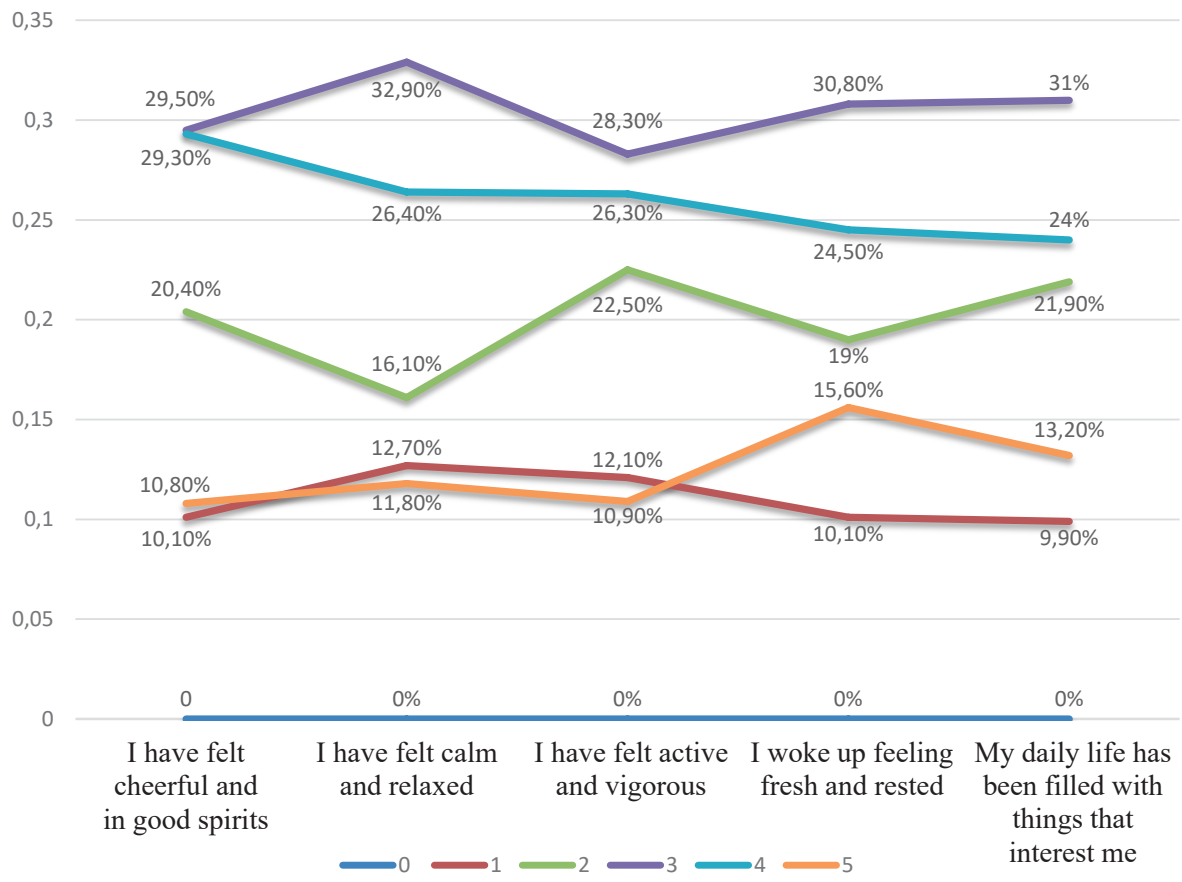

Fig. 5. Participants responses ( 0 - at no time, 1 - some of the time, 2 - less than half of the time, 3 - more than half of the time, 4 - most of the time, 5 - all the time) to statements on Quality of life (WHO Well-Being Index (1998 version)).

this period. This Pandemic crisis did not only affected the physical well-being but also people were more worried about the financial situation and its impact on their financial status in future. Related to financial well-being, $57 \%$ of the population responded that they had a reduced satisfaction with their financial situation and $13.6 \%$ felt financially stressed because of this. Out of total, $15.9 \%$ were worried about keeping their job or study which was not only harmful for their financial well-being but also more likely to affect their mental well-being. Majority (28.9\%) agreed on the statement that it was somewhat of financial hardship to them and their families. 
In our study the most positive responses were observed on emotional well-being. Most answers on emotional well-being were having zero score which indicates population had great control on emotional situations. In similar way, the sections of social and family wellbeing were also answered very positively. The participants (38.9\%) were very much happy with the support by their families and $37.7 \%$ felt satisfied with their communication with families. $32.7 \%$ felt very much close to their partners.

Emotional social and family wellbeing were responded positively by the majority of the participants, but the responses by some of the participants to several questions for disturbing too: $22 \%$ felt anxious and nervous over half of the days. They were not able to stop worrying. Nearly same percentage of the population felt too much worrying and they were feeling so restless that it was hard for them to sit or relax. Almost the same percentage of the population (23.7\%) became easily annoyed or irritable. They $(20.1 \%)$ felt afraid as a something awful might happen. However, these types of responses were given by $22 \%$ of population but still it is disturbing because it may have led to mental stress and mental health related issues to them. Out of total population, 29 to $32 \%$ felt cheerful, calm, relaxed, active, vigorous and fresh for more than half of the time.

Nevertheless, the results are not encouraging in terms of overall wellbeing of the population. Our findings indicate the need of serious attention on the quality of life and wellbeing of the population due to changes in lifestyle during the COVID-19 lockdown. It would be a huge challenge for not only the individuals to regain their physical, financial, emotional, mental, social and family wellbeing again but also for the government of India to re-establish the financial condition of the country by coping this pandemic crisis.

Limitations. Although, our study tried to involve population of all social economic and educational status, due to web-based study it wasn't feasible for the individuals of all socioeconomic status to take part in this study. Apart from this, shorter time span was also its one of the limitations. So, studies including larger sample size can be conducted.

\section{Conclusion}

Our findings suggest that lockdown has affected various aspects of life of each and every individual of the country. People are dealing this Pandemic with all their efforts but anxiety regarding future is making them weaker. Uncertainty of prevention and treatment of SARS-CoV2 is the major drawback to keep up the good spirit. The Lockdown has the transient benefit for prevention of spread but not a permanent solution to this problem.

\section{Conflict of Interests}

Authors declare no conflict of interest regarding this study.

\section{Funding}

This research received no external funding.

\section{Acknowledgements}

There had been no funding supports for carrying this research. The total cost of completing the research work was carried by authors' own finance.

\section{Author's Contributions}

Heena Rathi, Priyanka Rathi - conceptualization, methodology, formal analysis, writing - original draft, writing - reviewing and editing; Heena Rathi, Mohit Biyani - data curation, writing - reviewing and editing; Manisha Malik, Mohit Biyani - investigation; Manisha Malik - formal analysis.

\title{
ЯКІСТЬ ЖИТТЯ НАСЕЛЕННЯ ІНДІЇ В КІНЦІ ТРЕТЬОГО ЛОКДАУНУ, СПРИЧИНЕНОГО ПАНДЕМІЄЮ COVID-19
}

\author{
H. Rathi' ${ }^{1}$, M. Biyani ${ }^{2}$, M. Malik ${ }^{3},{ }^{*}$ P. Rathi ${ }^{4}$ \\ 1 - RUHS COLLEGE OF MEDICAL SCIENCES, JAIPUR, INDIA \\ 2 - SWAI MAN SINGH MEDICAL COLLEGE, JAIPUR, INDIA \\ 3 - PANDIT DEENDAYAL UPADHYAYA MEDICAL COLLEGE, CHURU, INDIA \\ 4 - MAHATMA GANDHI MEDICAL COLLEGE AND HOSPITAL, JAIPUR, INDIA
}

Вступ. 24 березня 2020 року уряд Індії впровадив загальнодержавний локдаун на 21 день, який потім було продовжено до 31 травня 2020 року. Дослідники передбачають, що обмеження пересування $\epsilon$ необхідним кроком для запобігання поширенню COVID-19. Однак також відомо, що че може завдати серйозної шкоди економічному, психічному, соціальному та фізичному благополуччю людей. 
Мета. Завдання цього дослідження - оцінити вплив локдауну на якість життя та добробут населення Індії.

Методи. Дослідення проводилося методом проспективного поперечного перерізу шляхом вебопитування. Було створено посилання (https://forms.gle/pX25VuahP5NxT88QA). Всього було отримано 426 відповідей за посиланням, і ці дані були проаналізовані.

Результати. Дослідження показало, що 61,5\% респондентів мали менше фізичне навантаження під час локдауну. Ще 57\% відповіли, що не задоволені своїм фінансовим становищем. Відповідь більшості мала позитивне забарвлення щодо емочійного благополуччя та соціально-сімейного благополуччя, але відповіді деяких опитаних мали тривожний характер: 22\% відчували занепокоєння та нервозність протягом майже всього періоду локдауну. Наше дослідження виявило, що фізичне, фінансове, емоційне, психічне, соціальне та сімейне благополуччя порушуються під час локдауну, також страждає якість життя.

Висновок. Незважаючи на те, що загальнодержавний локдаун, можливо і був найбільш необхідною дією для запобігання розповсюдженню вірусу, але наше дослідження показало, що невизначеність відносно лікування інфекції та рекомендацій щодо локдауну та соціального дистанціювання, мала значний вплив на якість життя та добробут населення.

КЛЮЧОВІ СЛОВА: пандемія; локдаун; COVID-19; тривога; якість життя.

Information about the authors India

Heena Rathi, B.D.S, MSc. (med-pharmacology) $3^{\text {rd }}$ year, RUHS College of Medical Sciences, Jaipur,

ORCID 0000-0002-8056-8768, e-mail: drheenarathi@gmail.com

Mohit Biyani, M.B.B.S, M.D (Anaesthesia) $2^{\text {nd }}$ year, Swai Man Singh Medical College, Jaipur, India ORCID 0000-0002-5543-6480, e-mail: mohit2.ncity@gmail.com

Manisha Malik, Associate professor, Pandit Deendayal Upadhyaya Medical College, Churu, India ORCID 0000-0001-8288-4206, e-mail: drmanishamalik@gmail.com

Priyanka Rathi, Associate professor, Mahatma Gandhi Medical College and Hospital, Jaipur, India ORCID 0000-0002-6400-6888, e-mail: drpriyankarathi@gmail.com

\section{References}

1. Maugeri G, Castrogiovanni P, Battaglia G, Pippi R, D'Agata V, Palma A, Di Rosa M, Musumeci G. The impact of physical activity on psychological health during Covid-19 pandemic in Italy. Heliyon. 2020 Jun 1;6(6):e04315. e04315

DOI: https://doi.org/10.1016/j.heliyon.2020.

2. Lesser IA, Nienhuis CP. The impact of COVID-19 on physical activity behavior and well-being of Canadians. International journal of environmental research and public health. 2020 Jan;17(11):3899.

DOI: https://doi.org/10.3390/ijerph17113899

3. Lades LK, Laffan K, Daly M, Delaney L. Daily emotional well-being during the COVID-19 pandemic. British journal of health psychology. 2020 Nov;25(4): 902-11.

DOI: https://doi.org/10.1111/bjhp.12450
4. Rodríguez-Rey R, Garrido-Hernansaiz H, Collado S. Psychological impact and associated factors during the initial stage of the coronavirus (COVID-19) pandemic among the general population in Spain. Frontiers in psychology. 2020 Jun 23;11:1540.

DOI: https://doi.org/10.3389/fpsyg.2020.01540

5. Kroenke K, Spitzer RL, Williams JB. The Patient Health Questionnaire-2: validity of a two-item depression screener. Medical care. 2003 Nov 1:1284-92.

DOI: https://doi.org/10.1097/01.MLR. 0000093487.78664.3C

6. Spitzer RL, Kroenke K, Williams JB, Löwe B. A brief measure for assessing generalized anxiety disorder: the GAD-7. Archives of internal medicine. 2006 May 22;166(10):1092-7.

DOI: https://doi.org/10.1001/archinte.166. 10.1092

Received 14 Dec 2020; revised 23 Dec 2020; accepted 28 Dec 2020

This is open access article distributed under the Creative Commons Attribution License, which permits unrestricted use, distribution, and reproduction in any medium, provided the original work is properly cited. 